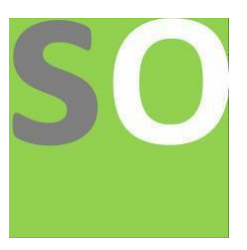

Article title: Design Of A Simple Water Level Indicator

Authors: Israel Nyityo [1], Fortune Nnaa[2], Isaac Terwase[3]

Affiliations: Department of Science, Divine Mercy Secondary School, Asokoro - Abuja Nigeria.[1], Department of Vocation and Technology, Divine Mercy Secondary School, Asokoro - Abuja Nigeria.[2], Department of Physics, Center for Food Technology and Research, Benue State University, Makurdi - Benue State, Nigeria.[3]

Orcid ids: 0000-0001-7985-2211[1]

Contact e-mail: nyityoi@gmail.com

License information: This work has been published open access under Creative Commons Attribution License http://creativecommons.org/licenses/by/4.0/, which permits unrestricted use, distribution, and reproduction in any medium, provided the original work is properly cited. Conditions, terms of use and publishing policy can be found at https://www.scienceopen.com/.

Preprint statement: This article is a preprint and has not been peer-reviewed, under consideration and submitted to ScienceOpen Preprints for open peer review.

DOI: 10.14293/S2199-1006.1.SOR-.PPNSQI0.v1

Preprint first posted online: 02 January 2022

Keywords: Water Level Indicator, Transistor, Resistor, WaterManagement 


\section{DESIGN OF SIMPLE WATER LEVEL INDICATOR}

${ }^{1}$ NYITYO, AONDONA ISRAEL.

${ }^{2} N N A A$ FORTUNE.

3 TERWASE, AONDONA ISAAC.

1 'DIVINE MERCY SECONDARY SCHOOL, ASOKORO ABUJA NIGERIA.

${ }^{3}$ CENTER FOR FOOD TECHNOLOGY AND RESEARCH, BENUE STATE UNIVERSITY MAKURDI NIGERIA.

November, 2021.

\begin{abstract}
This simple water level indicator is produced using electronic components such as transistors, resistors, capacitors and diodes to assemble a device which detects specific changes in water levels. It is designed to comfortably read 5 water levels, though this number can be navigated upwards or downwards with revised design specifications. The device is designed to be powered by a $6 v$ AC power source with the probes inserted according to corresponding lengths of the intended water levels to be detected during the calibration process.
\end{abstract}

Table of Contents

1.0 Introduction .1

2.0Materials and Methods 1

2.1 Materials 1

2.2 Methods 1

3.0Data and Results .........................

3.1 Observations/Results ...................3

4.0 Discussion of Results ................4

5.0 Conclusion .............................. 4

5.1 Practical Application...................4

5.2. Future Expansion...................... 4

References.

List of Figures.

Figure 1. Circuit diagram ....................... 1

Figure 2. Soldering components ...........2

Figure 3. Fixing LEDs box. ..................... 2
Figure 4. Schematic tank calibration .....2

Figure5: Physical calibration of tank .....2

Figure 6: Final coupling. 1

List of Tables

Table 1. Drainage data 3

Table 2. Pumping data

Key words: Water Level Indicator; Transistor; Resistor; Water Management.

1.0 Introduction

Availability of water resource in numerous regions of the world is decreasing at best and erratic at worse. A situation fast becoming a prevailing trend today. In response, The United Nations sustainability development goal number six seeks to ensure the availability and sustainable management of water and sanitation for all by 2030 [6]. This problem has come to live with us as a consequence of poor water allocation, inefficient use, and lack of adequate and integrated water management. Water running out in homes is a common problem, for even the most vigilant homes pumping water into a tank for usage. The sight of an overflowing tank on the other hand, has become a regular wasteful occurrence in our everyday societies. That is why it is becoming a matter of concern for efficient use and water monitoring and water management system for home or office [1].

In most places and systems where fluids are

stored and used, fluid management systems are designed in a way that the level of fluid may be easily seen with the naked eyes for

those in open surfaces and transparent containers. However, in opaque containers and closed systems such as overhead tanks, visualizing the fluid level becomes a difficult task and requires technological application [7].

Water level indicator is an instrument 
which can be easily implemented for use by rural communities in their households [2].This work looks to tackle the problem of sudden water shortage in the face of an availability to pump. It attempts to map out a relatively economical but viable solution to the problem, how do we know if our tank is running out of water? Is there a way we can set indicators to serve as warning bells for us?

\section{Materials and Methods}

\subsection{Materials}

1. Transistor NPN (T1-T5) BC 107

2. Resistors (R1-R5) 2.2K 1/4W

3. Resistors (R6-R10) $22 \mathrm{~K} 1 / 4 \mathrm{~W}$

4. Light Emitting diodes (LEDs) (Green) (D1-D5)

5. PVC pipes

6. Connecting wires

7. Transformer $6 \mathrm{~V}, 500 \mathrm{~mA}$

8. Insulated Aluminum wires for probes.

9. Plastic bucket (Tank).

\subsection{Methods:}

The circuit diagram was drawn first on paper before simulating on a breadboard to ensure it actually works.

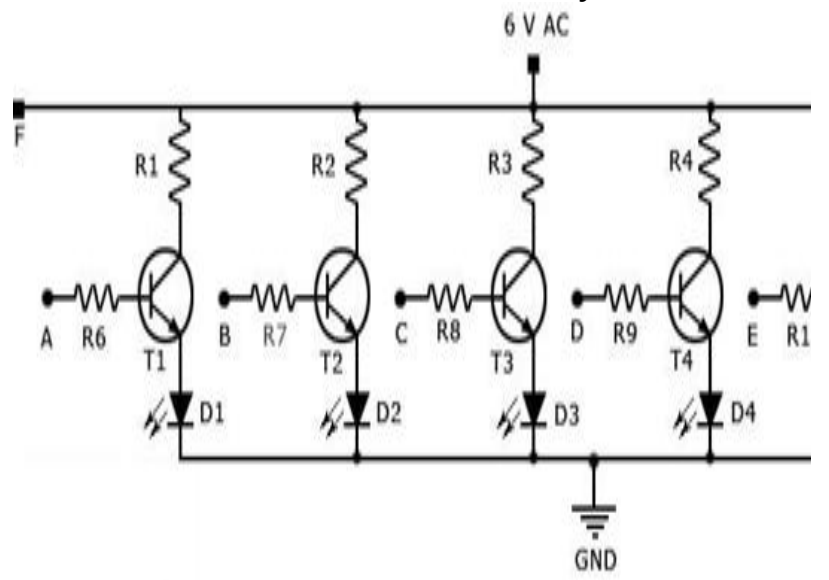

Figure 1. Circuit diagram for design of Simple Water Level Indicator The components were then assembled on the breadboard to test if the circuit actually works and can be implemented on vero boards.

The transistors were connected to the resistors and diodes on a vero board and soldered behind using soldering bits and a solder.

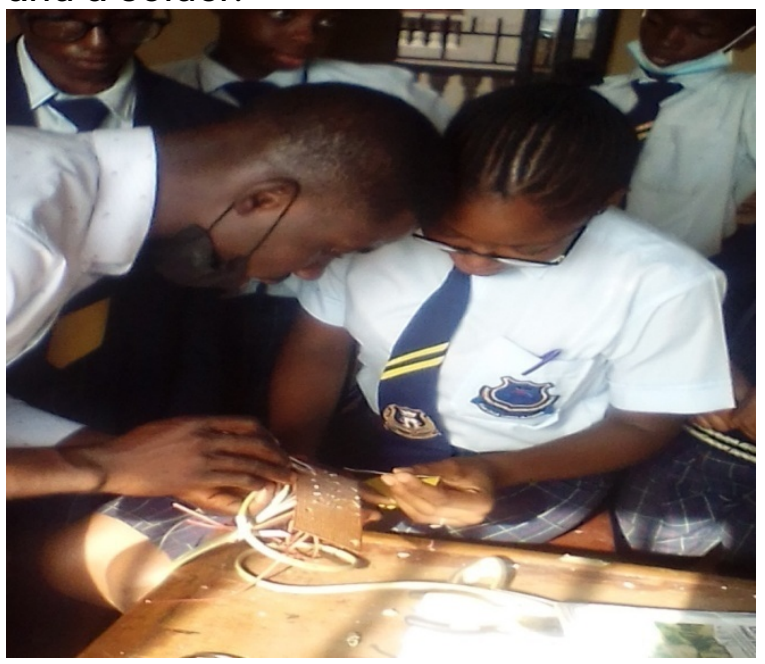

Figure 2. Soldering the components on the vero board.

The diodes are fixed on an enclosed box and connected to the circuit and then soldered.

Resistors R1, R2, R3 and R4 each of rating $2.2 \mathrm{~K} \Omega$ were then connected to the $6 \mathrm{~V}$ in the power unit, with a $500 \mathrm{~mA}$ transformer connected to the mains supply so as to provide the needed power for the device to function effectively.

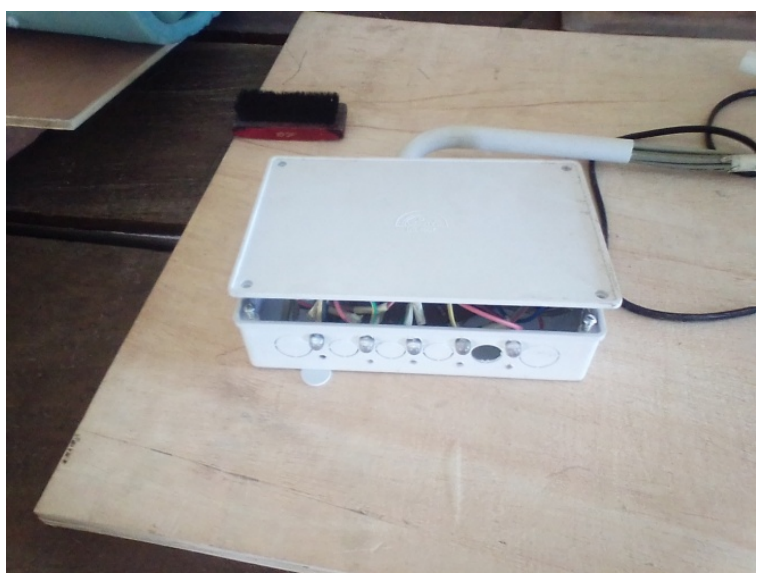

Figure 3. LEDs fixed to the enclosed box.

A bucket was then calibrated over the lengths of the wire to correspond to the schematic diagram below. The wires running deepest in the tank connects to 
the diode indicating an empty tank or the lowest water level. This implies the diode connected to it is the last to go off, indicating the tank is out of water.

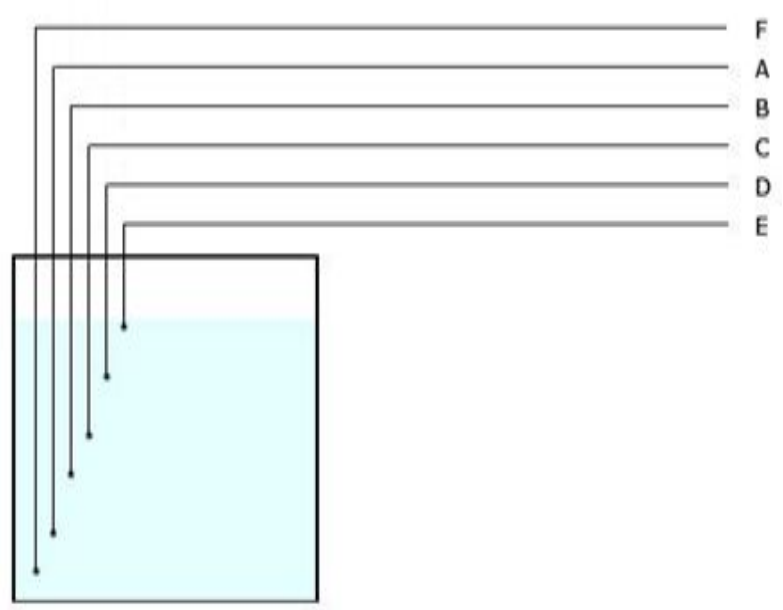

Figure 4. Schematic diagram of tank calibration

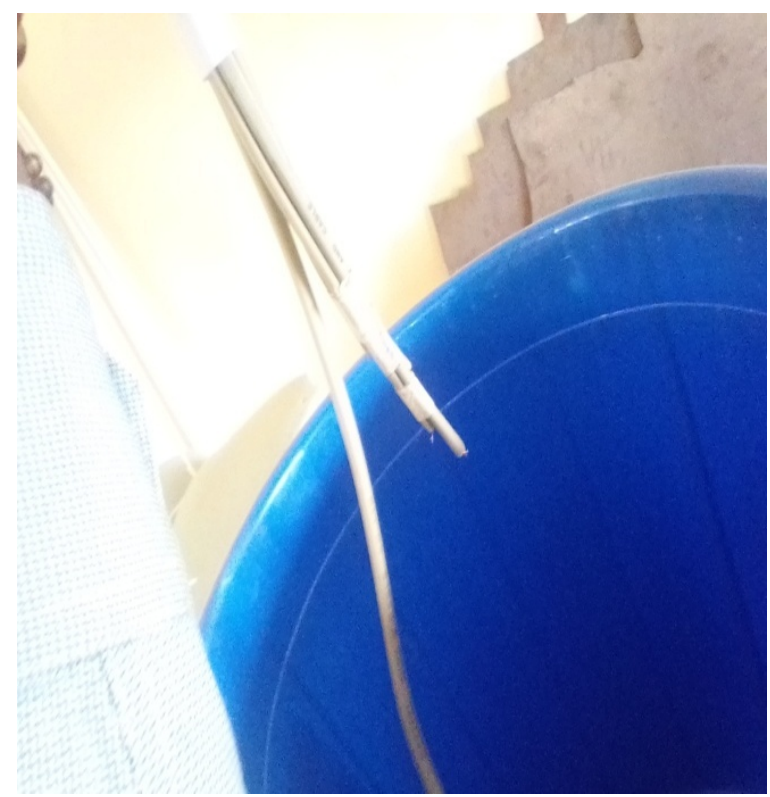

Figure 5: Physical calibration of tank.

The probes were then placed in the water tank and a lid bearing the device placed atop.

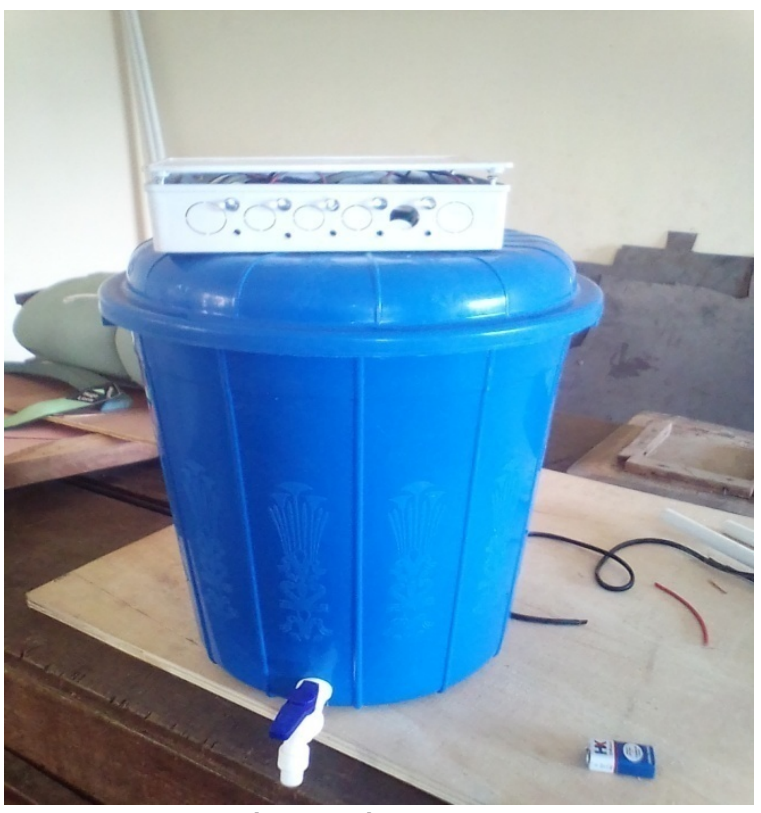

Figure 6: Final coupling.

2.0 Performance Test and

2.1 Observations/Results

When the tank was full, all the LEDs lit up. The performance test carried out on the device showed that, whenever water is filled up in the tank, all the 5 LEDs connected to the probes lit up. As the water gradually drained, the first LED goes off in response to the drop in water level. Further drain from the tank via the nozzle leads to the automatic switching off of LEDs in accordance with the water drop. The LED connected to probe $F$ deep at the bottom of the tank goes off when the water is entirely empty, indicating the water level has dropped to minimum. The final LED went off when the tank was entirely empty, indicating the water level had entirely dropped to minimum.

Table 1. Drainage data.

\begin{tabular}{ll}
\hline Water drained & Lighted LEDs \\
\hline Olitres & 5 \\
3litres & 4 \\
5litres & 3 \\
7litres & 2
\end{tabular}


9litres

12 litres

In the reverse process, water was added in to the tank (to represent pumping) and the following data was obtained as presented in the table below.

Table 2. Pumping data

\begin{tabular}{ll}
\hline Water pumped & Lighted LEDs \\
\hline Olitres & 0 \\
3litres & 1 \\
5litres & 2 \\
7litres & 3 \\
9litres & 4 \\
12litres & 5 \\
\hline
\end{tabular}

\subsection{Discussion of Results}

As the water is drained, the LEDs go off corresponding to the calibration of the tank. This explains why the number of LEDs lighted keeps reducing as we drain more liters of water.

\subsection{Conclusion}

The device has been observed to efficiently and effectively detect and indicate changes in the water levels. On pumping back the water into the tank, the bulbs come up once again.

\subsection{Practical Application}

This project finds a lot of relevance as it provides an efficient means of indicating the water level in a tank. With large scale implementation, its benefits can be greatly deployed in regimented areas like schools, military camps where a shortfall in water availability presents a massive hindrance to everyday activities.

\subsection{Future Expansion.}

This project holds the promise of an improvement by automotive upgrades. Linking the circuit to a pumping machine with a sensor, this detects critical water levels. On detection of depleted water levels to a critical level, the pump swings into action. The reverse side of it has the pump switching off automatically when the sensor senses that the tank is filled up.

A much more mechanical upgrade could come in the form of alarms that trigger to alert operators of critical water levels so they can turn on the pump and start or stop pumping.

\section{References}

[1] Sourove, A. M., Pratik, R., Golam, K., Sahid, H. and Samiul, I. (2016) "Construction of Digital Water Level and Automatic Pump Controlling System" Volume 03, Issue 12.www.researchgate.net.

[2] Govinda, S., Mansi, P., Gaurav, P. and Yogesh, P. (2015). Water Level Indicator (Volume 3, Issue 20) www.ijert.org.

[3] Paul, H., \&Windfied, R. (2008). The art of Electronics, (2nd Edition). London: Chand \& Company

[4] Melaty, A., Nurhakimah, M.M., Hana, A., and Nur, S.N. "Microcontroller Based Water Level Indicator Using GSM Modem: Design and Application", 1st International Conference on Future Trends in Computing and Communication Technologies, pp.79-83, 2012.

[5] Tharaja, B.L. \& Tharaja, A.K. (2006). A Text Book On Electrical

Technology, (23rd Edition). New Delhi, India: S, Chand \& Company.

[6] Hegarty, S., Hayes, A., (2021). Using Citizen Science to Understand River Water Quality while Filling Data Gaps to Meet United Nations Sustainable Development Goals Objectives, Science of the Total Environment, (Volume 783).

[7] Gesa, F. N., Terwase I. A., \& C. A. 
Chile (2020). Design and Implementation of a wireless Fluid Level Display System Using Ultrasonic Sensing Technique. Journal of Engineering and Research 